\title{
Effects of a convertible to-and-fro and circle anesthetic system on cardiopulmonary variables in isoflurane anesthetized horses
}

\author{
Efeitos de um sistema anestésico conversível vai-e-vem e circular nas variáveis cardiopulmonares em \\ cavalos anestesiados com isoflurano
}

\author{
Claudio Corrêa Natalini ${ }^{1}$, Alexandre da Silva Polydoro ${ }^{1}$, Ruben Lundgren Cavalcanti ${ }^{2}$, Luciana \\ Queiroga Branquinho², Nadia Crosignani ${ }^{2}$, Priscila Beatriz Serpa ${ }^{3}$, Rodrigo Gonçalves Schallenberger ${ }^{3}$, \\ Bruna Favieiro Pellin de Molnar ${ }^{3}$, Adriano Carregaro ${ }^{4} \&$ Fábio Futema ${ }^{5}$
}

\begin{abstract}
Six healthy adult horses two male and four female, mean body weight of $424 \pm 44.1 \mathrm{~kg}$, were anesthetized with xylazine, ketamine/diazepam and isoflurane for 60 minutes using a convertible to-and-fro and circle system. Variables analyzed were arterial blood $\mathrm{pH}$, carbon dioxide partial pressure $\left(\mathrm{PaCO}_{2}\right)$ and oxygen partial pressure $\left(\mathrm{PaO}_{2}\right)$, respiratory rate $(\mathrm{RR})$, and blood pressure. The horses were allowed to breath spontaneously, and were positioned in right lateral recumbency. The arterial $\mathrm{O}_{2}$ values were significantly higher during isoflurane anesthesia when compared to the baseline values, and significantly lower after induction with ketamine/diazepam although arterial hypoxemia were not present. The arterial $\mathrm{PCO}_{2}$ values were significantly higher from baseline values during isoflurane anesthesia occurring arterial hypercapnia and mild respiratory acidosis. The arterial $\mathrm{pH}$ changes paralleled the changes in $\mathrm{PaCO}_{2}$. Respiratory rate values were significantly lower during isoflurane anesthesia when compared to baseline values. All values remained within accepted range for lateral recumbent spontaneously breathing anesthetized horses. There were no significant differences between the circle and the to-and-fro system, demonstrating that either system is safe to maintain isoflurane anesthesia in adult horses.
\end{abstract}

Key words: isoflurane, anesthetic apparatus, equine, general anesthesia.

\section{RESUMO}

Seis eqüinos adultos hígidos, dois machos e quatro fêmeas foram estudados. O peso corporal dos animais foi de 424 $\pm 44.1 \mathrm{~kg}$. Estes foram sedados com xilazina e induzidos a anestesia geral com uma associação de ketamina e diazepam, e mantidos com isoflurano por 60 minutos, utilizando um sistema anestésico conversível do sistema vai-e-vem para o sistema circular. As variáveis analisadas foram o $\mathrm{pH}$ arterial sangǘneo, a pressão parcial arterial $\mathrm{de}_{\mathrm{CO}_{2}} \mathrm{e} \mathrm{O}_{2}$, a freqüência respiratória e a pressão arterial. Os eqüinos foram mantidos em respiração espontânea durante o estudo e posicionados em decúbito lateral direito. Os valores $\mathrm{de}^{\mathrm{PaO}}$, foram significativamente superiores aos valores basais e significativamente inferiores após a indução anestésica com quetamina/diazepam, embora não tenha ocorrido hipoxemia arterial. Os valores de $\mathrm{PaCO}_{2}$ foram significativamente superiores comparados com valores basais durante a anestesia com isoflurano, ocorrendo acidose respiratória e hipercapnia moderada. As alterações no $\mathrm{pH}$ sangüíneo acompanharam as alterações de $\mathrm{PaCO}_{2}$. A frequiência respiratória foi significativamente reduzida durante a anestesia com isoflurano quando comparada com os valores basais. Todos os parâmetros das variáveis estiveram dentro dos valores considerados normais para a espécie eqüina. Não foram evidenciadas diferenças significativas entre os dois sistemas, concluindo-se que ambos os sistemas podem ser utilizados para manutenção anestésica com isoflurano em eqüinos por um período de 60 minutos. O sistema anestésico proposto pode ser recomendado para uso clínico nesta espécie.

Descritores: isoflurano, aparelhos de anestesia, eqüino, anestesia geral.

${ }^{1}$ Departamento de farmacologia, Universidade Federal do Rio Grande do Sul (UFRGS), Centro de Pesquisas do Hospital de Clínicas de Porto Alegre (HCPA), Porto Alegre, RS/Brasil. ${ }^{2}$ Programa de Pós-graduação em Fisiologia, Instituto de Ciências Básicas da Saúde (ICBS), UFRGS. ${ }^{3}$ Faculdade de Veterinária (FaVet), UFRGS. ${ }^{4}$ Departamento de Clínica de Pequenos Animais, Universidade Federal de Santa Maria (UFSM), Santa Maria, RS/Brasil. ${ }^{5}$ Faculdade de Medicina Veterinária, Universidade de Guarulhos, São Paulo. CORRESPONDÊNCIA: C.C. Natalini [claudio.natalini@pq.cnpq.br]. 
Natalini C.C., Polydoro A.S., Cavalcanti R.L., Branquinho L.Q., Crosignani N., Serpa P.B., Schallenberger R.G., Molnar B.F.P., Carregaro A. \& Futema F. 2008. Effects of a convertible to-and-fro... Acta Scientiae Veterinariae.36(3):229-233.

\section{INTRODUCTION}

The anesthetic machine and breathing circuit for inhalation anesthesia delivers oxygen and anesthetic gases to the horse and remove carbon dioxide from the exhaled gases [1]. Halothane and isoflurane are the most commonly used inhalant anesthetic agents in horses. These agents are usually delivered in a semiclosed circle system or a valveless to-and-fro system using an out-of-the circuit vaporizer $[1,10]$.

In the horse, which is apparently predisposed to alveolar hypoventilation during inhalation anesthesia, it is suggested that adequate anesthetic apparatus design should be directed towards minimizing resistance and dead space and providing maximal and efficient carbon dioxide elimination. Resistance to breathing imposed by large animal anesthetic machine may contribute to increase work of breathing and ventilatory depression in anesthetized large animals [9].

The disadvantages of the to-and-fro breathing system are an excessive heat generated by the absorbent, however studies have shown no increase in the patients body temperature after 90 minutes of anesthesia, alkaline dust may be inhaled, relatively awkward to use, the soda lime nearest to the patient becomes expended first and increases mechanical dead space, and positioning the carbon dioxide absorption canister close to the patient head may be cumbersome $[1,8]$. Compared to a circle system, the to-and-fro anesthetic circuit is relatively simple and of rugged construction, easily disassembled for cleaning, easily transportable, and it is possible a relatively rapid change in anesthetic concentration for a given fresh gas flow [1].

Canister size is most critical in the to-and-fro system because the carbon dioxide content of the system progressively increases with time owing to increase mechanical dead space [7]. Too large or too small a canister causes rapid increase in apparatus dead space or carbon dioxide absorption is not complete, respectively [3]. The to-and-fro system may be used with an horizontal or vertical canister, filled with approximately 9 pounds of soda lime, and it can be used either as a semi-closed or closed system, the distinction between the two referring to the fresh gas flow rate $[1,8]$.

It has been described that using a semi-closed to-and-fro system with a vertical canister, oxygenhalothane anesthesia in horses, it is possible to carry out 120 minutes prolonged surgery without remarkable effects on blood gases and $\mathrm{pH}$ [11]. This study was designed to evaluate the effects of a toand-fro modified system, adding one liter mechanical dead space, on blood gases and respiratory rate in oxygen-isoflurane anesthetized horses, during 60 minutes using time as a factor.

\section{MATERIALS AND METHODS}

Six, matures healthy horses ( 2 geldings and 4 mares), $9.8 \pm 2.5$ years old, and weighting $424 \pm 44.1 \mathrm{~kg}$ were used. Food was withheld for 12 hours before each study. Water was available at all time. Immediately before each anesthetic induction respiratory rate was recorded, and an arterial blood sample was collected from the carotid or facial artery for $\mathrm{pH}$, carbon dioxide arterial partial pressure $\left(\mathrm{PaCO}_{2}\right)$, and oxygen arterial partial pressure $\left(\mathrm{PaO}_{2}\right)$ baseline determination. Noninvasive arterial blood pressure, end tidal carbon dioxide as well as respiratory and heart rate were also registered during the study time.

After sedation with intravenous (IV) xylazine ${ }^{1}$ $0.8 \mathrm{mg} . \mathrm{kg}^{-1}$, a 20 gauge, 2 inch catheter ${ }^{2}$ was percutaneuosly placed in the horse facial artery and a 14 gauge, 3.5 inch catheter $^{3}$ was introduced in the jugular vein, both sutured to the skin. Anesthetic induction was obtained with ketamine ${ }^{4}$ and diazepam combination combination at $2.0 \mathrm{mg} \cdot \mathrm{kg}^{-1}$ for ketamine and $0.1 \mathrm{mg} / \mathrm{kg}$ for diazepam IV, 15 minutes after sedation, and the horses positioned in right lateral recumbency.

After induction and tracheal intubation, each horse was connected to the anesthetic breathing circuit equipped with an isoflurane precision vaporizer. The anesthetic system was equipped with a horizontal 9 pounds $(4,5 \mathrm{~kg})$ capacity soda lime canister (Figure 1). The system was designed in such a way that adding two valves or removing them, it was possible to convert it from to-and-fro to circle or vice-versa. Oxygen flow rate was 10 liters/minute for the first 10 minutes and 5 liters/minute for the remaining time until the end of the study. Anesthesia was maintained with $3 \mathrm{~V} \%$ isoflurane $^{5}$ for the first 10 minutes and $1.5 \mathrm{~V} \%$ to $2 \mathrm{~V} \%$ during the remaining 20 minutes of inhalation anesthesia. Horses were maintained on circle and to-andfro system for 30 minutes in each system. System choice was randomized for each horse. Horses were allowed to breathe spontaneously.

Respiratory rate was determined by counting thoracic and abdominal excursions in one minute interval. Heparinized arterial blood samples were collected and refrigerated for $\mathrm{pH}$ and blood gas 


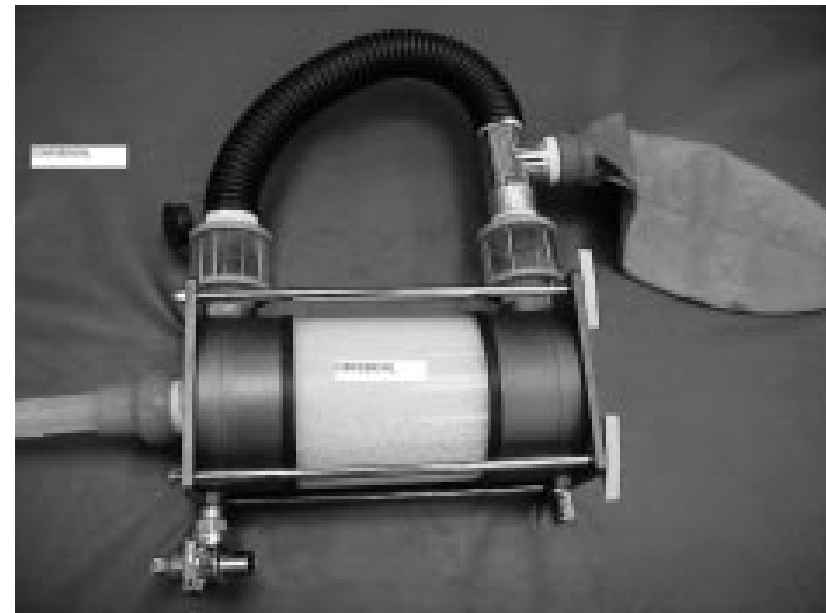

Figure 1. Large animal convertible anesthetic system equipped with two removable one-way valves.

analysis. Time for data and blood sample collection were T0 (baseline), T1 (10 minutes after sedation), T2 (after anesthetic induction), T3 (15 minutes of isoflurane anesthesia), T4 (30 minutes of isoflurane anesthesia), T5 (45 minutes of isoflurane anesthesia), and T6 (60 minutes of isoflurane anesthesia).

Data are presented as mean \pm standard deviation. One way repeated measure analysis of variance was used on one factor (time) and seven levels, for comparison. Bonferroni's method was used to isolate group or groups that differ from the others $(\mathrm{p}<0.05)$.

\section{RESULTS}

After xylazine administration all horses became heavily sedated showing classics signs of the alpha-2adrenoceptor agonist as indifference to their surroundings, dropping head, and lower lip flaccid. After ketamine/diazepam all horses became smoothly laterally recumbent and no central nervous system excitement or adverse effects were observed. All horses were easily intubated and positioned for the study. It was possible to maintain isoflurane anesthesia in all horses with vaporizer concentration between $1.5 \mathrm{~V} \%$ to $2.0 \mathrm{~V} \%$. All recoveries were considered normal. Anesthetic apparatus design has permitted an easy connection of the patient to the to-and-fro system.

The response variables parameters (mean \pm standard deviation) and statistical analysis are presented in Table 1. After anesthetic induction it was observed a non-significant $\mathrm{PaO}_{2}$ reduction from the baseline value without arterial hypoxemia $\left(\mathrm{PaO}_{2}<60 \mathrm{~mm} \mathrm{Hg}\right)$. After instituted oxygen-isoflurane anesthesia the $\mathrm{PaO}_{2}$ values were increased significantly. The $\mathrm{PaCO}_{2}$ values were increased progressively from baseline with significance from 15 to 60 minutes of isoflurane anesthesia. The $\mathrm{pH}$ values changed parallel to $\mathrm{PaCO}_{2}$, becoming significant after xylazine sedation. Respiratory rate decreased significantly after sedation and

Table 1. Blood gases, heart and respiratory rate (mean \pm Std Dev) in horses anesthetized with a convertible to-and-fro to circle system.

\begin{tabular}{|c|c|c|c|c|c|c|}
\hline Study Time & $\underset{(\mathrm{mm} \mathrm{Hg})}{\mathrm{PaO}_{2}}$ & $\begin{array}{c}\mathrm{ETCO}_{2} \\
(\mathrm{~mm} \mathrm{Hg})\end{array}$ & pH & $\begin{array}{l}\text { Respiration } \\
\text { (breaths/min) }\end{array}$ & $\begin{array}{c}\text { Arterial blood } \\
\text { pressure(mm } \mathbf{H g})\end{array}$ & $\begin{array}{c}\text { Heart rate } \\
\text { (beats/minute) }\end{array}$ \\
\hline Baseline & $105.8 \pm 15.74^{b}$ & $38.4 \pm 3.39^{b}$ & $7.44 \pm 0.04^{\mathrm{a}}$ & $21.22 \pm 7.63^{\mathrm{a}}$ & $110 \pm 10^{\mathrm{a}}$ & $44 \pm 09^{\mathrm{a}}$ \\
\hline $10 \mathrm{~min}$ & $98.6 \pm 12.74^{b}$ & $39.1 \pm 3.24^{\mathrm{b}}$ & $7.43 \pm 0.06^{\mathrm{a}}$ & $12.11 \pm 4.54^{\mathrm{b}}$ & $80 \pm 12^{\mathrm{a}}$ & $38 \pm 04^{\mathrm{a}}$ \\
\hline $20 \mathrm{~min}$ & $74.1 \pm 6.62^{\mathrm{b}}$ & $42.6 \pm 3.34^{\mathrm{b}}$ & $7.39 \pm 0.05^{\mathrm{b}}$ & $22.11 \pm 7.32^{\mathrm{a}}$ & $74 \pm 04^{b}$ & $31 \pm 02^{\mathrm{a}}$ \\
\hline $30 \mathrm{~min}$ & $229.7 \pm 57.74^{a}$ & $52.3 \pm 8.59^{\mathrm{a}}$ & $7.34 \pm 0.04^{\mathrm{bc}}$ & $9.78 \pm 3.38^{\mathrm{b}}$ & $70 \pm 04^{b}$ & $34 \pm 04^{\mathrm{a}}$ \\
\hline $40 \mathrm{~min}$ & $207.3 \pm 57.03^{a}$ & $56.1 \pm 9.04^{\mathrm{a}}$ & $7.33 \pm 0.04^{c}$ & $7.78 \pm 2.49^{b}$ & $60 \pm 10^{b}$ & $32 \pm 04^{a}$ \\
\hline $50 \mathrm{~min}$ & $175.4 \pm 49.02^{\mathrm{a}}$ & $56.8 \pm 11.73^{\mathrm{a}}$ & $7.32 \pm 0.05^{\mathrm{c}}$ & $8.33 \pm 2.69^{b}$ & $64 \pm 08^{b}$ & $36 \pm 02^{\mathrm{a}}$ \\
\hline $60 \mathrm{~min}$ & $191.0 \pm 76.03^{a}$ & $57.9 \pm 9.83^{\mathrm{a}}$ & $7.32 \pm 0.04^{c}$ & $9.33 \pm 2.24^{b}$ & $65 \pm 08^{b}$ & $34 \pm 02^{\mathrm{a}}$ \\
\hline
\end{tabular}

Means $\pm S D$ with the same letters are not significantly different. 
Natalini C.C., Polydoro A.S., Cavalcanti R.L., Branquinho L.Q., Crosignani N., Serpa P.B., Schallenberger R.G., Molnar B.F.P., Carregaro A. \& Futema F. 2008. Effects of a convertible to-and-fro... Acta Scientiae Veterinariae.36(3):229-233.

increased significantly after induction. During anesthetic period respiratory rate values were not significantly different from anesthetic induction. Heart rate as well as arterial blood pressure were significantly decreased after induction but not significantly different between systems.

\section{DISCUSSION}

For most efficient absorption of the carbon dioxide, the canister of the to-and-fro system should provide space between the granules equivalent to or greater than the animal's tidal volume, when filled with 9 pounds of soda lime $[8,12]$. We have used an horizontal, 9 pounds canister, which should provide enough space to contain one tidal volume of an adult horse. Due to canister placement to close to the animal when in use, heat produced by the exothermic chemical reaction of soda lime and $\mathrm{CO}_{2}$ in the presence of water does not have time to dissipate before gases are rebreathed [12]. Although it was not an intention in this study to measure the temperature inside the system, it is probable that the polypropylene plastic material we have used to make the apparatus aided to dissipate heat produced.

The to-and-fro system is most commonly used as a semi-closed method. With this method, the flow rates of $\mathrm{O}_{2}$ and anesthetic vapor will be greater than the animal's metabolic requirements. Using the system on a $500 \mathrm{~kg}$ horse, the $\mathrm{O}_{2}$ flow meter should be set to deliver 6 to $8 \mathrm{~L}$ per minute, and isoflurane vaporizer adjusted to provide 3 to 4 volumes per cent. The $\mathrm{O}_{2}$ flow rate and isoflurane percentage should be maintained until surgical anesthesia is induced, at which time the $\mathrm{O}_{2}$ flow rate reduced to 3 to $4 \mathrm{~L}$ per minute and the anesthetic vapor concentration reduced to 2 to 2.5 volumes per cent [12]. Results of our study confirm that an initial high $\mathrm{O}_{2}$ flow rate (10 $\mathrm{L}$ per minute) promote rapid induction to a medium anesthetic plane. We have maintained the $10 \mathrm{~L}$ per minute $\mathrm{O}_{2}$ flow rate during 10 minutes anesthetic period and reduced the isoflurane concentration from 3 to 1.5 or 2.0 volume per cent. With a $10 \mathrm{~L}$ per minute flow rate and a gas inlet adjacent to the exhaust valve, the expired gases were diluted in the added mechanical dead space, preventing the excess of $\mathrm{CO}_{2}$ build-up in the system.

Arterial hypercapnia during inhalation anesthesia in spontaneously breathing, clinically normal horses is produced by a combination of pharmacological depression of the respiratory center by anesthetic drugs and recumbency, with more dramatic effects induced by dorsal recumbency than lateral recumbency [4]. Impairment of pulmonary function can occur in horses positioned in lateral recumbency [5]. One study found that during spontaneously ventilation, horses in lateral recumbency anesthetized with isoflurane developed hypercarbia $\left(\mathrm{PaCO}_{2}=50\right.$ to $60 \mathrm{~mm} \mathrm{Hg}$ ), each horse was connected to a large animal circle breathing circuit [5]. In our study, $\mathrm{PaCO}_{2}$ increased significantly from baseline to 15 minutes of isoflurane anesthesia (time 3), although there was no significant increase within one hour of inhalation anesthesia. Our study investigating the to-and-fro system, confirms that a $10 \mathrm{~L}$ per minute $\mathrm{O}_{2}$ flow rate, maintain $\mathrm{PaCO}_{2}$ within acceptable limits in laterally recumbent isoflurane anesthetized horses during 30 minutes with the to-and-fro system.

Causes of arterial hypoxemia in general anesthetized horses are hypoventilation, alveolarcapillary membrane diffusion impairment, low inspired oxygen concentration, mismatching of pulmonary ventilation and perfusion, intrapulmonary shunt and decreased cardiac output [6]. Controversy exists concerning the clinical definition of hypoxemia. A $\mathrm{PaO}_{2}>200 \mathrm{~mm} / \mathrm{Hg}$ has been reported as a goal during the maintenance of inhalation anesthesia in horses [6]. Significant decrease in $\mathrm{PaO}_{2}$ were not observed in our horses, although during the maintenance phase of anesthesia, $\mathrm{PaO}_{2}$ values were bellow $200 \mathrm{~mm} / \mathrm{Hg}$ throughout 45 to 60 minutes of isoflurane. It can be explained because isoflurane anesthesia tends to reduce cardiac output, decreasing pulmonary blood flow, with consequent decrease in oxygen uptake. Arterial hypoxemia $\left(\mathrm{PaO}_{2}<60 \mathrm{~mm} / \mathrm{Hg}\right)$ was not observed in our study.

Our results showed that $\mathrm{pH}$ decreased as $\mathrm{PaCO}_{2}$ increased. In dogs, changes in $\mathrm{pH}$ produce hemodynamic variations [14]. As hemodynamic variables were not measured, we can not ascertain that the increased $\mathrm{pH}$ determined cardiovascular changes.

Depression of the respiratory and cardiovascular center usually occurs throughout general anesthesia in horses, with more dramatic effects induced by dorsal than lateral recumbency [2,4]. During severe hypercapnia horses under general anesthesia do attempt to breath spontaneously between ventilator-delivered breaths, although horses do not breath spontaneously during moderate hypercapnia when ventilated mechanically [13]. In our study, respiratory and heart 
rate as well as arterial blood pressure, decreased significantly throughout anesthetic period, which can be related to the anesthetic drugs used, and to lack in response to respiratory stimulation from elevated $\mathrm{PaCO}_{2}$. Differences between the to-and-fro system and the circle system were not detected. This founding indicates that the proposed apparatus is safe to maintain horses under isoflurane anthestesia for at least 60 minutes.

In conclusion, we demonstrated that the portable apparatus for inhalation anesthesia in horses evaluated in this study produces safe general anesthesia for at least 60 minutes, with acceptable reduction in respiratory and heart rate and mild hypercapnia.

\section{SOURCES AND MANUFACTURES}

${ }^{1}$ Sedazine, Fort Dodge Animal Health, Campinas/SP.

${ }^{2}$ Insyte, Becton and Dickinson Vascular Access - Sandy, Utah/USA.

${ }^{3}$ Intracath, Deseret Medical Inc. - Becton and Dickinson Company - Sandy, Utah/USA.

${ }^{4}$ Vetaset. Fort Dodge Animal Health, Campinas/SP.

${ }^{5}$ Isoflurano. Produtos Químicos e Farmacêuticos Ltda., São Paulo/SP.

\section{REFERENCES}

1 Bednarski R.M. 1991. Anesthetic equipment. In: Muir W.W. \& Hubbell J.A.E. (Eds). Equine Anesthesia, Monitoring and Emergency Therapy. St. Louis: Mosby Year Book, pp.325-351.

2 Day T.K., Gaynor J.S. \& Muir W.W. 1995. Blood gas values during intermittent positive pressure ventilation and spontaneous ventilation in 160 anesthetized horses positioned in lateral or dorsal recumbency. Veterinary Surgery. 18: 266-276.

3 Dorsch J.A. \& Dorsch S.E. 1984. Understanding Anesthesia Equipment. 2nd edn. Baltimore: Williams \& Wilkins, p.350.

4 Hall L.W., Gillespie J.R. \& Tyler W.S. 1968. Alveolar-arterial oxygen tension differences in anesthetized horses. British Journal of Anesthesia. 40: 560-568.

5 Hornof W., Dunlop C.I. \& Prestage R. 1986. Effects of lateral recumbency on regional function in anesthetized horses. American Journal of Veterinary Research. 47: 277-282.

6 Muir W.W. \& Hubbell J.A.E. 1991. Equine Anesthesia. Monitoring and Emergency Therapy. St. Louis: Mosby Year Book, p.515.

7 Purchase I.F.H. 1965. Function tests on four large animal anesthetic circuit. Veterinary Records. 77: 913-919.

8 Riebold T.W., Geiser D.R. \& Golble D.O. 1995. Large Animal Anesthesia. Ames: ISU, p.304.

9 Robinson N.E. 1991. The respiratory system. In: Muir W.W. \& Hubbell J.A.E. (Eds). Equine Anesthesia, Monitoring and Emergency Therapy. St. Louis: Mosby Year Book, pp.7-38.

10 Stefey E.P., Howland Jr. D., Giri S. \& Eger II E.I. 1977. Enflurane, halothane, isoflurane potency in horses. American Journal of Veterinary Research. 38: 1037-1039.

11 Stolk P.W.T. \& Lagerweij E. 1989. Use of the to-and-fro system in inhalation anesthesia produced in horses and ponies. Tijdschrmaatschappij voor Diergeneeskunde. 114: 657-667.

12 Thurmon J.C. \& Benson G.J. 1981. Inhalation anesthetic delivery equipment and its maintenance. Veterinary Clinics of North America: Large Animal Practice. 3: 73-97.

13 Wagner A. E., Bednarski R.M. \& Muir W.W. 1990. Hemodynamic effects of carbon dioxide during intermittent positivepressure ventilation in horses. American Journal of Veterinary Research. 51: 1922-1929.

14 Wexels J.C., Myhre E.S.P. \& Mjos O.D. 1985. Effects of carbon dioxide and pH on myocardial blood-flow and metabolism in the dog. Clinical Physiology. 5: 575-588.

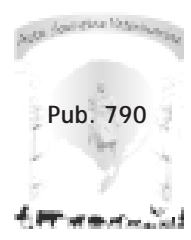

